\title{
Analysis of the Factors Affecting Delay in Housing Projects in XYZ Group)
}

\author{
Panji Bawono Saputro and I Putu Artama Wiguna \\ Departement of Technology Management, Institut Teknologi Sepuluh Nopember, Surabaya \\ e-mail:panbws@gmail.com
}

\begin{abstract}
Success in completing projects on time is one of the essential goals, both for the owner and the contractor. XYZ Group, a holding of several companies in the real estate, has delayed more than $53 \%$ of housing projects. The impact of delays is time overrun, cost overrun, deviations in the quality, disputes, negative social consequences, arbitration, and idling resources. This paper studied a list of construction delay causes gathered from the literature. It starts by exploring factors causing project delays from the research and finding 48 causative factors, followed by distributing preliminary questionnaires to expert respondents to obtain 23 causes for housing project delays. The primary survey held on 55 respondents consisting of technical directors, project managers, project engineers, quality control, logistics, and project planners. Relative Importance Index (RII) calculated, and according to the highest values, the top five delay causes of housing projects are determined. Objectives of project delays from the owner and contractor are "Late issuing of approval of design documents by the owner," and "Changing government political/economic situation or policy." The cause of project delays from the owner is "Shortage of labour from the contractor," "Changes to work completed by the owner," and "Failure of the contractor to complete the work." Meanwhile, "Slow delivery of resources required by the contractor," "Changes in details by the owner," "Rework due to quality and final results by the contractor," is the cause of project delays from the contractor.
\end{abstract}

Keywords-Cause of Delay, Contractor, Housing, Owner, Project Delay.

\section{INTRODUCTION}

$\mathrm{X}^{\mathrm{n}}$ YZ Group is a holding of several companies which have main activities in real estate services. The main activity of these companies is the construction of residential areas and public facilities in residential locations in East Java. Based on data from the engineering department, in January 2016 September 2019, there were more than 53\% of the delay in completion of housing project work. Different definitions of delay were found, and the delay is the most common, costly, complicated and risky problem encountered in construction projects. Delay is the time overrun either beyond the completion date specified in a contract or beyond the date that the parties agreed upon for delivery project, Assaf and AlHejji [1].

Kikwasi, Sambasivan and Soon in research on the impact of delays in construction projects in Tanzania and Malaysia, explain the impacts of delays such as time overrun, cost overrun, dispute, negative social impact, arbitration, total abandonment, litigation and idling resources [2-3]. The purpose of this study is to identify and analyze factors that are thought to cause delays in the implementation of housing projects in the XYZ Group.

Proboyo explained 45 factors causing a delay which was divided into several aspects, namely planning and scheduling, scope and work documents, organizational system, coordination and communication, preparedness/resource prepared, inspection system, control and evaluation work, and other (outside the ability of owners and contractors) [4].

Marzouk and El-Rasas focused on the causes of construction delays in the Egyptian construction industry [5]. The main objective of the research is to identify and rank the major causes of delays for engineering projects. The research was used interview and questionary survey to 33 experts in Egypt, identified 38 delay factor and classified under seven groups: owner, consultant, contractor, material, labour and equipment, project, and external.

Aziz and Abdel-Hakam in exploring delay causes of road construction projects in Egypt, identified 239 factors and determined the most significant factors [6]. It was classified under the following 15 primary classifications. Main factors of delays are owner financial problems/client finance/financial ability for the project, shortage in equipment/insufficient numbers, inadequate contractor experience (work) causing an error, shortage (availability) in construction materials, and equipment failure (breakdown).

Fallahnejad explored delay causes in Iran gas pipeline projects [7]. The researcher examined the previous 24 projects, including contract documents, correspondence, progress reports, minutes of meetings and final contractor reports regarding delays. It has identified 43 delay factors that divided into nine groups: the low ability of the contractor to provide imported material, unrealistic contract durations imposed by the client, slow delivery of material by the client, slow land expropriation due to resistance from occupants, clients' change orders, large quantities of extra work, type of project bidding and award, delays in contractor's payment by the client, obtaining permits from governmental organization, delays in suppliers and subcontractors' work, and contractor's poor cash flow management.

Hwang, Zhao, \& $\mathrm{Ng}$ on the research in critical factors affecting schedule in public housing projects in Singapore, identified 18 causes of a delay from the questionnaire from 115 respondent consist of the contractor, consultant and owner [8]. Top five causes of delays are site development, finance by contractor, coordinating parties, planning and scheduling, contractor experience.

Sweis et al explored the causes of delay in construction projects in Jordan [9]. Data on the study variables have been 
The $6^{\text {th }}$ International Seminar on Science and Technology (ISST) 2020

July $25^{\text {th }} 2020$, Institut Teknologi Sepuluh Nopember, Surabaya, Indonesia

Table 1.

Categorized groups that cause delay in projects

\begin{tabular}{|c|c|c|c|c|}
\hline $\mathrm{S} / \mathrm{N}$ & Stage & Category group item & $\begin{array}{l}\text { Related cause } \\
\text { ID }\end{array}$ & $\begin{array}{l}\text { Total number } \\
\text { of causes }\end{array}$ \\
\hline \multirow{2}{*}{01} & \multirow{2}{*}{ Planning } & Planning and scheduling related cause group & 01:06 & 6 \\
\hline & & Scope and work documents (contract) related cause group & 07:10 & 4 \\
\hline 02 & Procurement & Resource prepared related cause group & $11: 17$ & 7 \\
\hline 03 & Construction & Organizational system, coordination and communication related cause group & 18:31 & 14 \\
\hline 04 & $\begin{array}{l}\text { Control } \\
\text { Monitoring }\end{array}$ & Inspection system, control and evaluation work related cause group & $32: 41$ & 10 \\
\hline 05 & External & Other (outside the ability of owners and contractors) related cause group & 42:48 & 7 \\
\hline
\end{tabular}

collected through a structured questionnaire from 30 construction, consultant firms and owner located in Jordan. Significant causes of delays are bad planning and scheduling, lack of finance by contractor, change order from the owner, poor of labour skill and lack of competency by an engineer.

Sambasivan and Soon in causes and effects of delays in the Malaysian construction industry, identified 28 causes of a delay from the interview and questionnaire surveys from 30 consultants, owner and contractor [3].

Primary causes are contractor's improper planning, contractor's poor site management, inadequate contractor experience, client's finance and payments for completed work, problems with subcontractors, shortage in material, labour supply, equipment availability and failure, lack of communication between parties, mistakes during the construction stage.

Based on the synthesis of previous studies, 48 causes of delays were obtained and were divided into six (6) major groups and stages according to the project cycle, as shown ini Table 1 that causes delay in construction project, which are used in this paper, as follows; (1) Uneffective and unrealistic project schedule by owner; (2) Incomplete identification of work by the contractor; (3) Uncontrolling sequence work planning by the owner; (4) Unrealistic duration of work by owner; (5) Owner and contractor`s improper planning; (6) Ineffective construction method by the contractor; (7) Incomplete/conflicts of design drawings details and specifications; (8) Slow in design by owner; (9) Late issuing of approval of design documents by the owner; (10) The disagreement on design between contractor and owner; (11) Slow delivery of resources required by the contractor; (12) Shortage of labour from the contractor; (13) Shortage of material for contractor; (14) Shortage in equipment/insufficient numbers by contractor; (15) Financing by contractor during construction; (16) Owner financial problems; (17) Lack of material or equipment by owner; (18) The slowness of the owner decision-making process; (19) Difficulty of coordination between various parties (contractor and subcontractor) working on the project by owner; (20) Late land handover by owner/slow site clearance; (21) Insufficient communication between the owner and contractor or other parties; (22) Accidents during construction - labor injuries - infectious disease; (23) Unlimited pending by owner; (24) Additional order by owner during construction; (25) Changes to work completed by the owner; (26) Delay by sub-contractor from the contractor; (27) The contractor does not schedule the submission of sample material; (28) Delay in request and approval material samples by owner; (29) Slow permit by owner; (30) Changes in details by the owner; (31) Changes in scope of work by owner; (32) Slowly material test by owner; (33) Failure of the contractor to complete the work; (34) Rework due to quality and final results by the contractor; (35) Slowness progress evaluation by owner; (36) Inadequate supervision and regulation work by the owner; (37) The low productivity level of labours; (38) Poor qualification of the contractors technical staff; (39) Inefficient inspection and control of work by the owner; (40) Owner`s personal managerial skill and qualification; (41) Skill and motivation labour's by contractor; (42) Unforeseen site conditions; (43) Restricted access at site; (44) Act of God (Fire, flood, storm, earthquake); (45) Labour demonstration; (46) Riot, plague, war; (47) Vandalism by third party; (48) Changing government political/economic situation or policy [3-9].

This research aimed to identify the most important cause of delay that affects housing projects in XYZ Group, from owner and contractor perspective based on Relative Importance Index (RII) analysis.

\section{RESEARCH METHODS}

The methodology of this paper is listed as the following items; (1) Gathering the causes: The thoroughness of the literature review gathers several of 48 causes; (2) Defining the causes into groups: Different numbers of groups were found in the literature review, and it was found that for a particular cause, it can be placed in research in a group different from the other research; (3) The questionnaire survey: For the 48 different delay factors were identified. The questionnaires were developed into two major: Preliminary survey and main survey; (4) Distribute a preliminary survey and interview with six experts; (5) Distribute the primary survey, to get significant factors that cause delays in housing project XYZ Group. A 55 respondent that consist of technical directors, project managers, project engineers, quality control, logistics, and project planners. A five-point Likert scale ranging from 1 (not important) to 5 (extremely important) was used to categorize the importance of causes; (6) Take an instrument test: validity and reliability test; (7) Data are gathered and computing by using a RII, taking in view of owner and contractors. Agreement on the ranking of the importance of the causes of delay between the parties is analyzed.

\section{RESULT AND DISCUSSION}

\section{A. The Preliminary Survey}

The preliminary survey is held to eliminate the irrelevant causal factor found in the literature, which indicated never 
The $6^{\text {th }}$ International Seminar on Science and Technology (ISST) 2020

July $25^{\text {th }} 2020$, Institut Teknologi Sepuluh Nopember, Surabaya, Indonesia

Table 2.

Preliminary survey expert data

\begin{tabular}{lll}
\hline \hline ID & Position & Last Education \\
\hline Expert 1 & Technical Director & Bachelor Engineering \\
Expert 2 & Project Managers 1 & Bachelor Engineering \\
Expert 3 & Project Managers 2 & Bachelor Engineering \\
Expert 4 & Project Managers 3 & Bachelor Engineering \\
Expert 5 & Project Managers 4 & Bachelor Engineering \\
Expert 6 & Project Planner & Master Engineering \\
\hline \hline
\end{tabular}

Table 3.

Result of preliminary survey

\begin{tabular}{ll}
\hline \hline ID & Indicator \\
\hline X1 & Owner and contractor`s improper planning \\
X2 & Slow in design by owner \\
X3 & Late issuing of approval of design documents by the owner \\
X4 & The disagreement between working drawings between \\
X5 & contractor and owner \\
X6 & Show delivery of resources required by the contractor \\
X7 & Shortage of material for contractor \\
X8 & The slowness of the owner decision-making process \\
X9 & Changes to work completed by the owner \\
X10 & Delay by sub-contractor from the contractor \\
X11 & The contractor does not schedule the submission of sample \\
X12 & meterial \\
X13 & Slow in request and approvit by owner \\
X14 & Changes in details by the owner \\
X15 & Failure of the contractor to complete the work \\
X16 & Rework due to quality and final results by the contractor \\
X17 & Inadequate supervision and regulation work by the owner \\
X18 & The low productivity level of labours \\
X19 & Inefficient inspection and control of work by the owner \\
X20 & Unforeseen site conditions \\
X21 & Changing government political/economic situation or policy \\
X22 & Religious holiday \\
X23 & Rice planting season \\
\hline \hline &
\end{tabular}

happened and caused delays in the XYZ Group, involved six experts with working experience is more than 15 years in XYZ Group. Expert data can be seen on Table 2. From 48 causal factor that found, 27 factors eliminated dan adding two elements (Table 3 ). It can be seen in Table 3.

\section{B. The Main Survey}

A number of 55 respondents (technical directors, project managers, project engineers, quality control, logistics, and project planners) were distributed and valid responses valid responses were obtained. The collected data were analyzed through Relative Importance Index (RII) method. The analysis included ranking the different causes according to the relative importance indices. The analysis revealed the most contributing factors causing delays.

The causes of delay in housing projects will be looked at from different perspectives. Respondents profiles are included in the following Table 4 about the professionalism. The owner and contractor's data are shown in Table 5 and Table 6.

\section{Validity Test}

Validity test conducts to assess the validity of the questionnaire variables represented the measuring function of research. It using Pearson Product Moment Correlation 2tailed, significant factor 5\%, rtable: 0,2656.
Table 4.

Profession of respondent

\begin{tabular}{llll}
\hline \hline \multirow{2}{*}{$\mathrm{S} / \mathrm{N}$} & $\begin{array}{l}\text { Profession of } \\
\text { respondents }\end{array}$ & $\begin{array}{l}\text { Number of } \\
\text { respondents }\end{array}$ & Percentage (\%) \\
\hline 1 & Owners & 25 & 46 \\
2 & Contractors & 30 & 54 \\
Total & & 55 & 100 \\
\hline \hline
\end{tabular}

Table 5.

Owner respondent data

\begin{tabular}{|c|c|c|c|c|}
\hline $\mathrm{S} / \mathrm{N}$ & Category & & $\begin{array}{l}\text { Number of } \\
\text { respondents }\end{array}$ & $\begin{array}{l}\text { Percentage } \\
(\%)\end{array}$ \\
\hline \multirow{3}{*}{1} & \multirow{3}{*}{ Age } & $\leq 30$ years old & 4 & 16,00 \\
\hline & & $31-45$ years old & 17 & 68,00 \\
\hline & & $\geq 46$ years old & 4 & 16,00 \\
\hline \multirow{3}{*}{2} & \multirow{3}{*}{$\begin{array}{l}\text { Last } \\
\text { Education }\end{array}$} & $\begin{array}{l}\text { Senior high } \\
\text { school/ below }\end{array}$ & 11 & 44,00 \\
\hline & & $\begin{array}{l}\text { Diploma/Bachelor } \\
\text { degree }\end{array}$ & 12 & 48,00 \\
\hline & & $\begin{array}{l}\text { Master/ Doctorate } \\
\text { degree }\end{array}$ & 2 & 8,00 \\
\hline \multirow{4}{*}{3} & \multirow{4}{*}{$\begin{array}{l}\text { Years of } \\
\text { Experience }\end{array}$} & $\leq 5$ years & 5 & 20,00 \\
\hline & & $6-10$ years & 10 & 40,00 \\
\hline & & $11-20$ years & 9 & 36,00 \\
\hline & & $\geq 21$ years & 1 & 4,00 \\
\hline
\end{tabular}

Table 6.

Contractor respondent data

\begin{tabular}{|c|c|c|c|c|}
\hline $\mathrm{S} / \mathrm{N}$ & Category & & $\begin{array}{l}\text { Number of } \\
\text { respondents }\end{array}$ & $\begin{array}{l}\text { Percentage } \\
(\%)\end{array}$ \\
\hline \multirow{3}{*}{1} & \multirow{3}{*}{ Age } & $\leq 30$ years old & 3 & 10,00 \\
\hline & & $31-45$ years old & 15 & 50,00 \\
\hline & & $\geq 46$ years old & 12 & 40,00 \\
\hline \multirow{4}{*}{2} & \multirow{4}{*}{$\begin{array}{l}\text { Last } \\
\text { Education }\end{array}$} & $\begin{array}{l}\text { Senior high } \\
\text { school/below }\end{array}$ & 17 & 56,67 \\
\hline & & $\begin{array}{l}\text { Diploma/Bachelor } \\
\text { deoree }\end{array}$ & 13 & 43,33 \\
\hline & & Master/ Doctorate & & \\
\hline & & degree & 0 & 0,00 \\
\hline \multirow{4}{*}{3} & \multirow{4}{*}{$\begin{array}{l}\text { Years of } \\
\text { Experience }\end{array}$} & $\leq 5$ years & 3 & 10,00 \\
\hline & & $6-10$ years & 10 & 33,33 \\
\hline & & $11-20$ years & 11 & 36,67 \\
\hline & & $\geq 21$ years & 6 & 20,00 \\
\hline
\end{tabular}

Each factor that causes a delay in the primary survey calculated by Eq. 1 .

$$
\mathbf{r}=\frac{n \sum X Y-\sum X \sum Y}{\sqrt{\left(n \sum X^{2}-\left(\sum X\right)^{2}\right)\left(\mathrm{n} \sum Y^{2}-\left(\sum \mathrm{Y}\right)^{2}\right)}}
$$

Where $r$ is Pearson Correlation; $n$ is the total number of respondents; $\mathrm{X}$ is Independent Variable (score for each question); $\mathrm{Y}$ is the Dependent Variable (total score for every question). The result of validity test can be seen on Table 7. Value of Pearson Correlation each factor computed and compared to $r_{\text {table. If the value of the Pearson Correlation is }}$

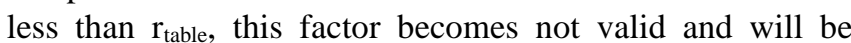
eliminated from this research.

Validity test eliminates two invalid factors (X13 and X23) because Pearson Correlation/r less than $r_{\text {table }}$. There are 21 delay factors for this research (Table 7).

\section{Reliability Test}

Reliability test using a Cronbach-alpha method. Twentyone factors from validity test, compute using Eq. 2 and result of reliability test can be seen on Table 8 .

$$
r=\left(\frac{n}{n-1}\right)\left(1-\frac{\sum \sigma_{t}^{2}}{\sigma_{t}^{2}}\right)
$$


The $6^{\text {th }}$ International Seminar on Science and Technology (ISST) 2020

July $25^{\text {th }} 2020$, Institut Teknologi Sepuluh Nopember, Surabaya, Indonesia

Table 7.

Result of validity test

\begin{tabular}{cllll}
\hline \hline ID & $\begin{array}{l}\text { Pearson } \\
\text { Correlation } / \mathrm{r}\end{array}$ & Result & Conclusion & Mean \\
\hline $\mathrm{X} 1$ & 0.4535 & $\mathrm{r}>\mathrm{r}_{\text {table }}$ & Valid & 3.3273 \\
$\mathrm{X} 2$ & 0.3774 & $\mathrm{r}>\mathrm{r}_{\text {table }}$ & Valid & 3.3636 \\
$\mathrm{X} 3$ & 0.3381 & $\mathrm{r}>\mathrm{r}_{\text {table }}$ & Valid & 3.6364 \\
$\mathrm{X} 4$ & 0.4928 & $\mathrm{r}>\mathrm{r}_{\text {table }}$ & Valid & 3.0000 \\
$\mathrm{X} 5$ & 0.4922 & $\mathrm{r}>\mathrm{r}_{\text {table }}$ & Valid & 3.2364 \\
$\mathrm{X} 6$ & 0.4297 & $\mathrm{r}>\mathrm{r}_{\text {table }}$ & Valid & 3.3636 \\
$\mathrm{X} 7$ & 0.5983 & $\mathrm{r}>\mathrm{r}_{\text {table }}$ & Valid & 2.9091 \\
$\mathrm{X} 8$ & 0.4497 & $\mathrm{r}>\mathrm{r}_{\text {table }}$ & Valid & 3.0364 \\
$\mathrm{X} 9$ & 0.5627 & $\mathrm{r}>\mathrm{r}_{\text {table }}$ & Valid & 3.2909 \\
$\mathrm{X} 10$ & 0.4253 & $\mathrm{r}>\mathrm{r}_{\text {table }}$ & Valid & 3.2182 \\
$\mathrm{X} 11$ & 0.4104 & $\mathrm{r}>\mathrm{r}_{\text {table }}$ & Valid & 2.9273 \\
$\mathrm{X} 12$ & 0.3851 & $\mathrm{r}>\mathrm{r}_{\text {table }}$ & Valid & 3.0182 \\
$\mathrm{X} 13$ & 0.1158 & $\mathrm{r}<\mathrm{r}_{\text {table }}$ & Not Valid & 3.4727 \\
$\mathrm{X} 14$ & 0.4905 & $\mathrm{r}>\mathrm{r}_{\text {table }}$ & Valid & 3.1455 \\
$\mathrm{X} 15$ & 0.4714 & $\mathrm{r}>\mathrm{r}_{\text {table }}$ & Valid & 3.1273 \\
$\mathrm{X} 16$ & 0.3530 & $\mathrm{r}>\mathrm{r}_{\text {table }}$ & Valid & 3.4000 \\
$\mathrm{X} 17$ & 0.4836 & $\mathrm{r}>\mathrm{r}_{\text {table }}$ & Valid & 2.8727 \\
$\mathrm{X} 18$ & 0.5820 & $\mathrm{r}>\mathrm{r}_{\text {table }}$ & Valid & 3.0727 \\
$\mathrm{X} 19$ & 0.3346 & $\mathrm{r}>\mathrm{r}_{\text {table }}$ & Valid & 2.9636 \\
$\mathrm{X} 20$ & 0.3114 & $\mathrm{r}>\mathrm{r}_{\text {table }}$ & Valid & 3.0182 \\
$\mathrm{X} 21$ & 0.4331 & $\mathrm{r}>\mathrm{r}_{\text {table }}$ & Valid & 3.4182 \\
$\mathrm{X} 22$ & 0.3382 & $\mathrm{r}>\mathrm{r}_{\text {table }}$ & Valid & 2.7818 \\
$\mathrm{X} 23$ & 0.0061 & $\mathrm{r}<\mathrm{r}_{\text {table }}$ & Not Valid & 2.6909 \\
\hline \hline
\end{tabular}

Where $\mathrm{r}$ is Cronbach-alpha; $\mathrm{n}$ is the total number of question item; $\sum \sigma_{t}^{2}$ is the total score of variances each item; $\sigma_{t}^{2}$ is total variance. If alpha score $>0.60$, variable in this questionnaire is reliable, if alpha score $>0.60$, variable in this questionnaire is not reliable. The reliability test found that 21 factors are reliable and these factors used on research (Table $8)$.

\section{E. Ranking of Delay Causes}

To provide a degree of importance for each delay cause, an important index was calculated in the same way as shown in Eq. (3).

$$
R I I=\sum_{i=1}^{N} W i F i /(A * N)
$$

Where RII is Relative Importance Index of each factor for each group of respondents; $\mathrm{Wi}$ is the weighting given to each factor by the respondents (ranging from 1 to 5); Fi is the frequency of respondent for each weight; $\mathrm{A}$ is the highest weight and $\mathrm{N}$ is the total number of respondents.

This formula was used by Aziz and Abdel-Hakam, Gebrehiwet and Luo, Aibinu and Odeyinka and Doloi et al. [6, 10-12]. The result of analysis Relative Importance Index (RII) can be seen on Table 9 .

\section{1) Ranking of Delay Causes Under Each Group}

RII analysis was conducted on 25 respondents from the owner and 30 respondents from the contractor. RII calculation is done on 21 variables divided into several stages of the project to get the highest-ranking factor to the lowest.

Based on Table 9, there is a common perception between the owner and the contractor based on RII's calculations about the cause of the delay in housing projects in the XYZ Group on the planning stage. From the owner and contractor, the essential cause is filled by variable $\mathrm{X} 3$, namely "Late issuing of approval of design documents by the owner" with a calculated RII (Relative Importance Index) value of 0.760 from the owner's side and a calculated RII value of 0.700 of contractor side.
Table 8.

Result of reliability test

\begin{tabular}{cll}
\hline \hline Cronbach's Alpha & N of items & Conclusion \\
\hline$\frac{\text { Alpha }}{0.7949}$ & 21 & Reliable \\
\hline \hline
\end{tabular}

Table 9.

Result of RII on planning stage

\begin{tabular}{|c|c|c|c|c|c|}
\hline \multirow{2}{*}{\multicolumn{2}{|c|}{ Cause }} & \multicolumn{2}{|c|}{ Owner } & \multicolumn{2}{|c|}{ Contractor } \\
\hline & & RII & Rank & RII & Rank \\
\hline \multicolumn{6}{|c|}{ Delay group: planning and scheduling } \\
\hline $\mathrm{X} 1$ & $\begin{array}{l}\text { Owner and contractor`s } \\
\text { improper planning }\end{array}$ & 0,712 & 3 & 0,693 & 2 \\
\hline \multicolumn{6}{|c|}{ Delay group: scope and work documents (contract) } \\
\hline $\mathrm{X} 2$ & $\begin{array}{l}\text { Slow in design by owner } \\
\text { Late issuing of approval }\end{array}$ & 0,728 & 2 & 0,660 & 3 \\
\hline $\mathrm{X} 3$ & $\begin{array}{l}\text { of design documents by } \\
\text { the owner }\end{array}$ & 0,760 & 1 & 0,700 & 1 \\
\hline X4 & $\begin{array}{lr}\text { The } & \text { disagreement } \\
\text { between } & \text { working } \\
\text { drawings } & \text { between } \\
\text { contractor and owner }\end{array}$ & 0,664 & 4 & 0,547 & 4 \\
\hline
\end{tabular}

Table 10.

Result of RII on procurement stage

\begin{tabular}{|c|c|c|c|c|c|}
\hline \multirow{2}{*}{\multicolumn{2}{|c|}{ Cause }} & \multicolumn{2}{|c|}{ Owner } & \multicolumn{2}{|c|}{ Contractor } \\
\hline & & RII & Rank & RII & Rank \\
\hline \multicolumn{6}{|c|}{ Delay group: resource prepared } \\
\hline X5 & $\begin{array}{l}\text { Slow delivery of } \\
\text { resources required by the } \\
\text { contractor }\end{array}$ & 0.672 & 2 & 0.673 & 1 \\
\hline X6 & $\begin{array}{l}\text { Shortage of labour from } \\
\text { the contractor }\end{array}$ & 0.704 & 1 & 0.667 & 2 \\
\hline $\mathrm{X} 7$ & $\begin{array}{l}\text { Shortage of material for } \\
\text { contractor }\end{array}$ & 0.664 & 3 & 0.560 & 3 \\
\hline
\end{tabular}

On Table 10, there are differences between the owner and the contractor regarding the most influence the cause of the delay. From the owner, the most crucial cause is filled by variable X6, namely "Shortage of labour from the contractor" with the calculated RII (Relative Importance Index) value of 0.704. Whereas from the contractor, it was the X5, " Slow delivery of resources required by the contractor " with a calculated RII (Relative Importance Index) of 0.673.

As seen in Table 10, there are differences in perceptions between the owner and the contractor regarding the delay in housing projects in XYZ Group based on the results of RII calculations. From the owner's point of view, an essential cause is filled by variable X9, namely " Changes to work completed by the owner " with a calculated RII (Relative Importance Index) value of 0.672 . Whereas from the contractor's point of view, it was found that the variable X14, namely " Changes in details by the owner," was the most crucial cause with the calculated RII (Relative Importance Index) value of 0.660 .

As seen in Table 11, found differences between the owner and the contractor regarding an essential cause of the delay based on analyzing of RII. From the owner, the most crucial cause is X15, "Rework due to quality and final results by the contractor" with a calculated RII of 0.744 (Table 12). While from the contractor, it was found that the X16, "Performing rework related to quality and final results by the contractor," was the most crucial cause with RII calculation value of 0.627 . 
The $6^{\text {th }}$ International Seminar on Science and Technology (ISST) 2020

July $25^{\text {th }} 2020$, Institut Teknologi Sepuluh Nopember, Surabaya, Indonesia

Table 11.

Result of RII on construction stage

\begin{tabular}{|c|c|c|c|c|c|}
\hline \multirow{2}{*}{ Cause } & & \multicolumn{2}{|l|}{ Owner } & \multicolumn{2}{|c|}{ Contractor } \\
\hline & & RII & Rank & RII & Rank \\
\hline $\begin{array}{l}\text { Delay } \\
\text { comn }\end{array}$ & $\begin{array}{l}\text { group: organizational } \\
\text { nication }\end{array}$ & \multicolumn{2}{|c|}{ system, } & coordination & and \\
\hline $\mathrm{X} 8$ & $\begin{array}{l}\text { The slowness of the } \\
\text { owner decision-making } \\
\text { process }\end{array}$ & 0.616 & 4 & 0.620 & 3 \\
\hline X9 & $\begin{array}{l}\text { Changes to work } \\
\text { completed by the owner }\end{array}$ & 0.672 & 1 & 0.653 & 2 \\
\hline $\mathrm{X} 10$ & $\begin{array}{l}\text { Delay by sub-contractor } \\
\text { from the contractor }\end{array}$ & 0.656 & 3 & 0.620 & 3 \\
\hline $\mathrm{X} 11$ & $\begin{array}{l}\text { The contractor does not } \\
\text { schedule the submission } \\
\text { of sample material }\end{array}$ & 0.544 & 6 & 0.600 & 6 \\
\hline $\mathrm{X} 12$ & $\begin{array}{l}\text { Delay in request and } \\
\text { approval material } \\
\text { samples by owner }\end{array}$ & 0.608 & 5 & 0.607 & 5 \\
\hline $\mathrm{X} 14$ & $\begin{array}{l}\text { Changes in details by } \\
\text { the owner }\end{array}$ & 0.664 & 2 & 0.660 & 1 \\
\hline
\end{tabular}

Table 12.

Result of RII on control and monitoring stage

\begin{tabular}{|c|c|c|c|c|c|}
\hline \multirow{2}{*}{ Caus } & & \multicolumn{2}{|l|}{ Owner } & \multicolumn{2}{|c|}{ Contractor } \\
\hline & & RII & Rank & RII & Rank \\
\hline \multicolumn{6}{|c|}{$\begin{array}{l}\text { Delay group: inspection system, control and evaluation work related } \\
\text { cause group }\end{array}$} \\
\hline $\mathrm{X} 15$ & $\begin{array}{l}\text { Failure of the contractor } \\
\text { to complete the work }\end{array}$ & 0.744 & 1 & 0.580 & 5 \\
\hline X16 & $\begin{array}{l}\text { Rework due to quality } \\
\text { and final results by the } \\
\text { contractor }\end{array}$ & 0.728 & 2 & 0.627 & 1 \\
\hline $\mathrm{X} 17$ & $\begin{array}{l}\text { Inadequate supervision } \\
\text { and regulation work by } \\
\text { the owner }\end{array}$ & 0.568 & 5 & 0.613 & 2 \\
\hline $\mathrm{X} 18$ & $\begin{array}{l}\text { The low productivity } \\
\text { level of labours }\end{array}$ & 0.632 & 3 & 0.593 & 3 \\
\hline X19 & $\begin{array}{l}\text { Inefficient inspection } \\
\text { and control of work by } \\
\text { the owner }\end{array}$ & 0.616 & 4 & 0.593 & 3 \\
\hline
\end{tabular}

There is a common perception between the owner and the contractor based on the results of RII calculations, according to Table 13. The essential cause is variable X21, "Changing government political/economic situation or policy" with a calculated RII value of 0.712 from the owner's side and a calculated RII value amounting to 0.640 from the contractor Based on the results of the RII analysis found eight dominant factors causing delays in housing projects in the XYZ Group, both from the perspective of the owner and from the contractor. All these factors are presented in Table 14.

\section{CONCLUSSIONS}

Based on analysis of RII, identified eight significant factors cause of delays in XYZ Group. The cause of project delays from the owner and contractor are "Late issuing of approval of design documents by the owner," and "Changing government political/economic situation or policy." The owner has significant factors for delays. It is "Shortage of labour from the contractor,"Changes to work completed by the owner," and "Failure of the contractor to complete the work." The cause of project delays from the contractor is "Slow delivery of resources required by the contractor," "Changes in details by the owner," "Rework due to quality and final results by the contractor."
Table 13.

Result of RII on external stage

\begin{tabular}{llllll}
\hline \hline \multirow{2}{*}{ Cause } & \multicolumn{2}{c}{ Owner } & \multicolumn{2}{c}{ Contractor } \\
RII & Rank & RII & Rank \\
\hline $\begin{array}{l}\text { Delay group: other (outside the ability of } \\
\text { related cause group }\end{array}$ & site & 0.640 & 2 & 0.633 & 2 \\
$\mathrm{X} 20$ & $\begin{array}{l}\text { Unforeseen } \\
\text { conditions } \\
\text { Changing government }\end{array}$ & & & & \\
$\mathrm{X} 21$ & $\begin{array}{l}\text { political/economic } \\
\text { situation or policy }\end{array}$ & 0.712 & 1 & 0.640 & 1 \\
$\mathrm{X} 22$ & \begin{tabular}{l} 
Religious holiday \\
\hline
\end{tabular} & 0.600 & 3 & 0.620 & 3 \\
\hline
\end{tabular}

Table 14.

Result of RII analysis

\begin{tabular}{|c|c|c|}
\hline Stage & Owner & Contractor \\
\hline A. Planning & \multicolumn{2}{|c|}{$\begin{array}{l}\text { Scope and work documents (contract) } \\
\text { X3: Late issuing of approval of design documents } \\
\text { by the owner, RII: Rank } 1 \\
\text { Resource prepared }\end{array}$} \\
\hline \multirow[t]{2}{*}{$\begin{array}{l}\text { B. } \\
\text { Procurement }\end{array}$} & RII: Rank 2 & $\begin{array}{l}\text { X5: Slow delivery of } \\
\text { resources required by } \\
\text { the contractor, RII: } \\
\text { Rank } 1\end{array}$ \\
\hline & $\begin{array}{l}\text { X6: Shortage of labor } \\
\text { from the contractor, RII: } \\
\text { Rank } 1\end{array}$ & RII: Rank 2 \\
\hline \multirow[t]{2}{*}{$\begin{array}{l}\text { C. } \\
\text { Construction }\end{array}$} & $\begin{array}{l}\text { Organizational system, } \\
\text { communication } \\
\text { X9: Changes to work } \\
\text { completed by the owner, } \\
\text { RII: Rank } 1\end{array}$ & coordination \\
\hline & RII: Rank 2 & $\begin{array}{l}\text { X14: Changes in } \\
\text { details by the owner, } \\
\text { RII: Rank } 1\end{array}$ \\
\hline \multirow{2}{*}{$\begin{array}{l}\text { D. Control } \\
\text { and } \\
\text { Monitoring }\end{array}$} & $\begin{array}{l}\text { Inspection system, control a } \\
\text { X15: Failure of the } \\
\text { contractor to complete the } \\
\text { work, RII: Rank } 1\end{array}$ & RII: Rank 5 \\
\hline & RII: Rank 2 & $\begin{array}{l}\text { X16: Rework due to } \\
\text { quality and final } \\
\text { results by the } \\
\text { contractor, RII: Rank } \\
1\end{array}$ \\
\hline E. External & $\begin{array}{l}\text { Other (outside the abi } \\
\text { contractors) } \\
\text { X21: Changing governm } \\
\text { situation or policy, RII: Ran }\end{array}$ & $\begin{array}{l}\text { ty of owners and } \\
\text { nt political/economic }\end{array}$ \\
\hline
\end{tabular}

\section{REFERENCES}

[1] S.A. Assaf and S. Al-Hejji, "Causes of delay in large construction projects," International Journal of Project Management, 2006, pp. 349-357.

[2] G.J. Kikwasi, "Causes and Effects of Delays and Disruptions in Construction Projects in Tanzania." Australasian Journal of Construction Economics and Building - Conference Series, 2012, pp. 52-59.

[3] M. Sambasivan and Y. W. Soon, "Causes and effects of delays in Malaysian construction industry." International Journal of Project Management, 2007, pp. 517-526.

[4] B. Proboyo, 'Keterlambatan Waktu Pelaksanaan Proyek: Klasifikasi Dan Peringkat Dari Penyebab-Penyebabnya". Dimensi Teknik Sipil, Vol. 1, no.1, pp. 49-58, Maret 1999.

[5] M.M. Marzouk and T.I El-Rasas, "Analyzing Delay Causes in Egyptian Construction Projects.” Journal of Advanced Research, 2014, pp. $49-55$.

[6] R.F. Aziz and A.A. Abdel-Hakam, "Exploring delay causes of road construction projects in Egypt," Alexandria Engineering Journal, 2016, pp. 1515-1539.

[7] M.H. Fallahnejad, "Delay causes in Iran gas pipeline projects," International Journal of Project Management, 2013, pp. 136-146. 
The $6^{\text {th }}$ International Seminar on Science and Technology (ISST) 2020

July $25^{\text {th }} 2020$, Institut Teknologi Sepuluh Nopember, Surabaya, Indonesia

[8] B.G. Hwang, X. Zhao and S.Y. Ng, "Identifying the critical factors affecting schedule performance of public housing projects." Habitat International, 2013, pp. 214-221.

[9] G. Sweis, R. Sweis, A. Abu Hammad, and A. Shboul, "Delays in construction projects: The case of Jordan," International Journal of Project Management, 2008, pp. 665-674.

[10] T. Gebrehiwet and H. Luo, "Analysis of Delay Impact on Construction Project Based on RII and Correlation Coefficient: Empirical Study.” in

Creative Construction Conference 2017 (CCC 2017), 2017, pp. 366374.

[11] A. Aibinu and H. Odeyinka, "Construction delays and their causative factors in Nigeria," Journal Construction Engineering Management 2006, pp. 667-677.

[12] H. Doloi, A. Sawhney, K.C. Iyer, S. Rentala, "Analysing factors affecting delays in Indian construction projects", International Journal Project Management, 2012, pp. 479-489. 